\title{
Az iskolai báNTALMAZÁs (BUlLying) MEGELŐZÉSE
}

\author{
JÁRMI ÉVA
}

ELTE PPK Iskolapszichológia Tanszék

\begin{abstract}
Bár a bullying jelenségének kiterjedtsége napjainkban még módszertani nehézségek miatt nehezen meghatározható, az oktatási-nevelési intézmények és a társadalom részéről is egyre nagyobb igény körvonalazódik az iskolai bántalmazás megértésére és kezelésére. A hatékony antibullying programok közös jellemzői, hogy prevenciós szemléletüek, hangsúlyozzák az antibullying csoportnormák kialakítását, valamint az ismeretátadás mellett attitüdöt is formálnak és viselkedéses készségeket is fejlesztenek. A tanulmány célja, hogy áttekintést adjon a hazai antibullying gyakorlatokról (pl. ENABLE, KIVA, NyugiOvi): az eddig megvalósultakról és a további fejlesztési irányokról.
\end{abstract}

Kulcsszavak: bullying, antibullying program, prevenció, ENABLE, KIVA, NyugiOvi, Prevention of Bullying In School Setting

Although the exact scope of bullying is hard to determine due to methodological difficulties, there is a rising demand on behalf of the educational institutions and the society to better understand and manage bullying. Common features of effective antibullying programs are the preventive approach, the emphasis antibullying group norms and besides education these programs develop behavioural skills and change attitudes. The goal of the present study is to give an overview about antibullying programs in Hungary (e.g. ENABLE, KIVA, NyugiOvi): what has been done and what needs to be developed.

Keywords: bullying, antibullying programs, prevention, ENABLE, KIVA, NyugiOvi

\section{Bevezetés}

$\mathrm{H}$ úsz évvel ezelött éppen az Educatio címü folyóiratban jelent meg Dan Olweus (1999) Iskolai zaklatás címü 1995-ös tanulmánya magyarul. Azóta számos hazai kutató foglalkozott a témával, több tanulmány, illetve könyv áll magyarul is a bullying jelensége iránt érdeklődő kutatók, pedagógusok, pszichológusok és a

Levelező szerző: Jármi Éva, ELTE PPK, 1075 Budapest, Kazinczy u. 23-27. IV. em. 423.

E-mail: jarmi.eva@ppk.elte.hu 
gyermeküknek segíteni próbáló szülők rendelkezésére. A hazai kutatások terén történt előrelépésekről jó áttekintést ad Buda Mariann összefoglaló írása (2015), jelen tanulmányban ezért a gyakorlatra, vagyis az iskolai bántalmazás megelőzését, illetve kezelését célzó programokra, módszerekre fókuszálunk, és csak röviden térünk ki a bullying hazai elterjedtségének kérdésére.

A bullying problematikájának előtérbe kerülését sokáig akadályozta, hogy az egyetlen nagymintás vizsgálat, ami érintette a bullying elterjedtségét - az Iskoláskorúak Egészségmagatartása (HBSC) kutatás - nemzetközi összehasonlításban alacsony prevalenciát jelzett hazánkban (Németb-Költő 2016): 2013/2014-es adatfelvételnél az 5-11. évfolyamos diákok 5,1 százaléka számolt be arról, hogy legalább heti rendszerességgel bántalmazzák az iskolában, és csak 3 százalékuk vallotta magát elkövetőnek, amivel bőven a részt vevő országok $10 \%$ körüli átlaga alatt vagyunk. De vajon tényleg ilyen jó a helyzet, vagy valamilyen módszertani oka van ennek a pozitív képnek? A HBSC kutatásban a diákoknak bemutatják a bullying (kortársbántalmazás) Olweusféle definícióját, ennek elolvasása után kell megítélniük érintettségüket. Nem tudjuk azonban, hogy valóban elolvasta-e, megértette-e, illetve hogyan értelmezi a válaszadó a viszonylag hosszú és nehezen érthető definíciót, és tudja-e használni ezt a fogalmat élményei felidézésénél. Az Oktatáskutató és Fejlesztő Intézet kutatói 2015-ben felső tagozatos diákok országos reprezentatív mintáján egy másik megközelítést alkalmaztak (Simon-Zerinváry-Velkey 2015): 13 specifikus bullying viselkedést soroltak fel, ezek előfordulásáról kellett beszámolniuk a diákoknak. Így az áldozatok (akik legalább egy bántalmazástípust legalább heti rendszerességgel elszenvednek) aránya 15,2 százalék, a bántalmazóké 7 százalék. A definíciós nehézségek mellett felmerül továbbá az önbeszámoló megbízhatóságának kérdése, ami ráadásul a válaszadó életkorával, nemével és érintettségével is összefügg (pl. idősebb fiúk kevésbé szívesen vallják magukat áldozatnak, mint a fiatalabb fiúk vagy a lányok). Kortársmegítélés esetén viszont az nehezíti az érintettek meghatározását, hogy gyakran alacsony konszenzus van az osztálytársak között adott diák bullying szerepéről (pl. néhányan bántalmazónak jelölik, mások védelmezőnek, és többen kívülállónak ugyanazt a diákot). Felmerül még az is, hogy nem is az érintettek száma, hanem az osztályban előforduló bullying incidensek mennyisége és súlyossága jelzi jobban a probléma nagyságát, hiszen a bullying a szemlélőkre nézve is komoly negatív következményekkel jár. Összefoglalóan tehát azt mondhatjuk, hogy még számos módszertani kérdés vár megválaszolásra, hogy egyértelmű képet kaphassunk a probléma súlyáról (Várnai et al. 2018).

A továbbiakban igyekszünk áttekintést adni arról, hogy mi történt az antibullying programok/gyakorlatok fejlesztése és iskolai bevezetése terén hazánkban az elmúlt években, hol tartunk most, és milyen irányba lehet, illetve kell továbblépni a jövőben.

\section{Előzmények: a probléma felismerése}

Preventív programok kidolgozásának előfeltétele, hogy tisztában legyünk a megelözendő problémával. Ez triviális lépés a balesetmegelőzés vagy az egészségkárosító magatartások esetében, de a bullying definiálása már korántsem egyértelmű. Sokan még ma is megkérdőjelezik, hogy lehet-e, illetve érdemes-e

- a kortársak között előforduló bántó magatartás számos formáját egy kategóriába sorolni: pl. megalázó beszólások, kiközösítés, gyengébb diák megverése; 
- mindezeket más agresszív megnyilvánulásoktól elkülöníteni: pl. erőszakos konfliktuskezelés, bosszúállás, indulatkitörés, önvédelem;

- majd erre a mesterségesen kialakított kategóriára (bullying) megfelelő magyar kifejezést találni? ${ }^{1}$

A hazai szakmai közönség csak lassan kezdte magáévá tenni azt a gondolatot, hogy

1. létezik bullying a magyar iskolákban is,

2. ez nem természetes velejárója a diákközösségeknek, hanem egy probléma, ami ellen fel kellene lépni,

3. nemcsak a bántalmazott diákok, hanem az egész osztályközösség védelme érdekében,

4. és a hatékony fellépés felelőssége a tanároké (vagyis nem hárítható a diákokra vagy a családra).

Az iskolai agresszió átmenetileg jelentős figyelmet kapott 2008-2009 folyamán, amikor több eset súlyos tragédiával végződött, illetve felkerült az internetre, így nagy sajtóvisszhangot keltett. Ennek nyomán a Mérei Ferenc Pedagógiai és Pályaválasztási Intézet keretei között egy Agressziókezelési Munkacsoport alakult, ami akkor megfogalmazott küldetése szerint „olyan komplex támogatást kínál az oktatási-nevelési intézmények számára, amely a problémák felszíni kezelésén túlmutat. A program a bajok gyökeres orvoslására törekszik, gyerekeket és felnőtteket egyaránt a konfliktusok békés feloldására, az együttmüködés fontosságára tanítva" (Fótiné Németh 2010: 5). Ez a komplex intézményfejlesztés mérésen alapuló, helyi igényekre választ adó, többféle módszertani elemet ötvöző kezdeményezés volt, amely jó példája az angolszász szakirodalomban "whole school approach"-nak nevezett megközelítésnek. Budapesten kb. 20 iskolában vezettek be resztoratív eljárásokat, képeztek kortárssegítőket, a diákok színházi nevelési foglalkozásokon vettek részt, és mindezt kiegészítette vezetői tréning, illetve környezetfejlesztés, mint pl. az „erőszak hot-spotok” felszámolása. Sajnos a projekt lezárása után csak elszórtan, helyi szintü kezdeményezésként tudtak ezek a módszerek, gyakorlatok egy-egy iskolában megjelenni (példák erre az Iskolai Konfliktusok Tudásközpont honlapján: http://iskon.opkm.hu/).

Az elmúlt évtizedben egy másik oldalról kapott erősítést a bullying-prevenció: a gyermekek, fiatalok egyre korábban kezdődő és egyre jelentősebb internethasználata ráirányította a figyelmet az ebben rejlő veszélyekre. Az aggódó, a digitális világban magukat elveszettnek érző pedagógusok, illetve szülők számára rengeteg információs anyag készült a témában, amelyek segítségével fel tudják készíteni a gyermekeket a helyes online magatartásra és a különböző internetes veszélyekkel szembeni védekezésre, mint pl. a cyberbullying (internetes bántalmazás). A legjelentősebb ma is müködő projekt az Európai Bizottság által indított Safer Internet Program, amelyet hazánkban a Nemzetközi Gyermekmentő Szolgálat és a Kék Vonal Gyermekkrizis Alapitvány működtet (bővebben erről lentebb).

Az utóbbi 4-5 évben több (kiemelt) Európai Unió által finanszírozott pályázat kapcsolódott az iskolai bántalmazás megelőzését célzó programok fejlesztéséhez, illetve társadalmi érzékenyítésre alkalmas eszközök, gyakorlatok kidolgozásához, terjesztésé-

A tanulmányban az iskolai bántalmazás kifejezést használom, de gyakran találkozhatunk a bullying hazai irodalmában az iskolai zaklatás, kortársbántalmazás, iskolai erőszak, megfélemlítés terminusokkal is. 
hez, és ma már számos szervezetnek - állami, civil, piaci háttérrel - vannak szolgáltatásai ezen a téren. Elsőként három átfogó antibullying programot ismertetünk: az óvodásoknak szóló NyugiOvi Programot, az 1-5. évfolyamon bevezethető KiVa Programot és a serdülő korosztálynál alkalmazható ENABLE Programot. Ezek a programok jól illeszkednek egymáshoz, hiszen azonos elméleti alapokon nyugszanak, és hasonló megközelítéssel, elemekkel, módszerekkel dolgoznak - persze mindezt adott korosztály és az intézményi felépítés sajátosságaihoz igazítva.

\section{Átfogó bullying-megelőző programok hazánkban}

\section{Az átfogó bullying-prevenciós programok koncepciója}

A preventív programoknak mindig három fó komponense van: az ismeretátadás mellett attitüdöt is formálunk és viselkedéses készségeket is fejlesztünk (Jármi-Piros 2017). Antibullying programjaink célkitűzései ezért összetettek:

1. Kognitív szint: első lépésként tudatosítani kell, hogy az iskolai bántalmazás komoly probléma. Informálni kell a diákokat, a tanárokat és a szülőket a bántalmazás jelenségéről, elterjedtségéről, a kialakulásához vezető pszichológiai mechanizmusokról és következményeiről. Kiemelt jelentőséggel bír

- az iskolai bántalmazás rejtettebb formáinak (indirekt bullying, cyberbullying) bemutatása,

- az áldozat érzéseinek, szenvedésének hangsúlyozása,

- az áldozat hibáztatása helyett a csoport szerepének tisztázása.

2. Viselkedéses szint: minden érintettnek tudnia kell, mit tegyen, ha valakit bántalmaznak, hogyan lehet megállítani a bántalmazást áldozatként, szemlélőként, szülőként, tanárként, melyek a hatékony, de biztonságos védekezési/védelmi stratégiák. Fontos, hogy a program

- ne csak irányelveket, hanem konkrét tanácsokat is nyújtson,

- hogy a beavatkozási technikák megtanítása mellett lehetőséget adjon ezek begyakorlására,

- egyértelmüen határozza meg, kihez lehet segítségért fordulni a bántalmazás megállítása érdekében.

3. Érzelmi/motivációs szint: A diákokat buzdítani kell arra, hogy valóban alkalmazzák ismereteiket és készségeiket, hiszen csak akkor fognak tenni valamit, ha úgy érzik, megéri az erőfeszítés. Ehhez szükséges

- bántalmazásellenes attitüd és csoportnorma kialakítása,

- az árulkodás tabujának megtörése a bántalmazás jelentése érdekében.

Az átfogó antibullying programok gerincét az osztályközösségeknek tartott foglalkozások alkotják, melyeket lehetőleg a csoport formális vezetője (osztályfőnök, ill. óvodapedagógus) tart. Ezek eredményeként kerülnek megfogalmazásra és elfogadásra azok a bullying-ellenes osztályszabályok, melyek explicitté teszik a közösség normáit és az elvárt viselkedést - ezért is fontos a csoport vezetőjének minél aktívabb részuétele a folyamatban. A közösség normaképzése, a szemlélők mozgósítása mellett mindig része a tematikának a társas-érzelmi készségek fejlesztése is, hiszen ezek (érzelmi tudatosság, érzelemszabályozás, együttműködés, közös problémamegoldás, segítségnyújtás, segít- 
ségkérés, konstruktív konfliktusrendezés és asszertivitás) általában is hozzájárulnak a pozitív csoportlégkörhöz, illetve a bántalmazás minden érintettjének segítenek abban, hogy ki tudjanak lépni szerepükből.

A csoportfoglalkozások megtartására mindig fel kell készíteni a pedagógusokat, de valójában az intézmény minden dolgozóját szükséges érzékenyíteni, és egységes nevelöi környezetet teremteni a bántalmazás megelőzéséhez szükséges kompetenciák fejlesztésével. Cél, hogy a pedagógusok vegyék észre és határozottan állítsák le a bántalmazó viselkedést, illetve az intézménynek legyen olyan eljárásrendje, amely resztoratív szemléletben, egységesen kezeli az előforduló bullying incidenseket.

Mivel a bullying megelőzésében fontos szerepet játszik az otthoni környezet és a családból hozott minták is, ezért a pedagógusok képzése mellett fontos elem a szülők minél szélesebb körű bevonása, melyet tematikus szülöi értekezletek és a szülőknek szóló kiadványok segítenek.

\section{A NyugiOvi Program}

A NyugiOvi Program a TÁMOP-5.2.10-15/1-2015-0001 „Kora-gyermekkori program a megfélemlités megelözésére" című pályázat keretében született meg 2015-ben. Célja az óvodai bántalmazás elleni fellépés erősítése, ami az iskolai bántalmazás megelőzését is szolgálja. A csoportfoglalkozások öt téma, öt szabály köré épülnek, ezek bevezetése változatos tevékenységi formákon keresztül történik, harmonizálva az Óvodai nevelés országos alapprogramjával ( $\mathrm{pl}$. anyanyelvi nevelés, mozgás, ábrázolás, ének-zene).

1. Mindenkit befogadunk a csoportba. Az első hét célja a csapatépítés, a közösségi érzés, a mi-tudat erősítése, egymás elfogadásának és a különbözőségek tolerálásának elősegítése.

2. Elmondjuk, amit érzünk. A gyerekek megtanulják felismerni és kifejezni érzelmeiket, illetve olyan technikákat sajátítanak el, melyek elősegítik az indulatkezelést, a félelmek leküzdését, ezáltal is csökkentve a bántalmazás, illetve az áldozattá válás esélyét.

3. Nem bántjuk egymást. A játékos foglalkozáson keresztül a gyerekek megismerik a bántalmazás különböző formáit, illetve azt, hogy ezek milyen érzést váltanak ki a bántalmazott társukban. Arra is kitérünk, hogy a bocsánatkérés nem elegendő, a kapcsolat helyreállításához szükséges a jóvátétel, valamint a másik megvigasztalása is.

4. Megvédjük, ha valakit bántanak. A gyerekek a foglalkozás során megtapasztalhatják, hogy bennük is megvannak a szükséges „szuperképességek” ahhoz, hogy a gyengék védelmére keljenek, és akkor tudjuk megvédeni egymást, ha egyesítjük az erőinket. A hatalmaskodó gyerek valójában nem erős, az erő nem a bántásban, hanem a védelemben van.

5. Szólunk, ha valakit bántanak. A jelzés nem egyenlő az árulkodással, így a gyerekek megtanulják elkülöníteni, hogy melyek azok az esetek, mikor a másik bajban van és szólni kell a felnőttnek. Zárásként összegezzük az eddigi tevékenységeket, valamint a gyerekekkel együtt vállaljuk, hogy minden csoporttag betartja a megtanult szabályokat.

A NyugiOvi foglalkozások egy mesés kerettörténetbe vannak ágyazva, melynek föszereplője egy távoli bolygóról érkező, védelemre szoruló űrlény (Szepi), aki leveleken keresztül kommunikál a gyerekekkel. Az ő befogadását és biztonságát szolgálják a bántal- 
mazásellenes csoportszabályok, a betartásukhoz szükséges társas-érzelmi készségeket pedig két tündérfigurával való azonosulás révén fejlesztjük: a tündérlány (Zille) kívül hordja szívét, ezért mindig megérzi, ha valaki fél, bánatos és segítségre van szüksége, tündérlovag társa (Timó) pedig varázspajzsa segítségével mindenkit meg tud védeni. A történet nem ér véget a projekt végén, hiszen tartós hatást csak akkor várhatunk, ha a program fö üzenetei a gyermekek mindennapjainak részévé tudnak válni. Ennek érdekében vezetik be az óvodapedagógusok a Zille/Timó-felelősök rendszerét, akiknek feladatuk a társaik biztonságára való figyelés és az esetleges bántalmazás jelzése, a magányos gyerekek játékba hívása, megvigasztalása. Az óvoda dolgozói, ha bántalmazást tapasztalnak - bármilyen formában bárkinél - mindig azonos módon lépnek fel (ti. a közösen elfogadott óvodai szabályra és a másik fájdalmára való hivatkozással leállítják a bántónak címkézett viselkedést), az óvodapedagógusok pedig mindig a reaktív kör technikáját alkalmazzák, aminek célja a kapcsolatok helyreállítása. A gyerekeket az egységes nevelői fellépés, a resztoratív kérdések (mi történt, ki mit érez, mire lenne szüksége, hogy rendbe jöjjenek a dolgok) és a békítő eljárás rituáléja segíti a kívánt társas viselkedés elsajátításában.

A csoportfoglalkozásokhoz tartozó pedagógusképzés és szülöi alkalmak mellett további programelemek (színházi előadás, kampánynap, állapotfelmérés) is kiegészítik a NyugiOvi koncepciót. Mindazonáltal az óvodákból érkező érdeklődés és szakmai igény ellenére a program széles körben történő bevezetése - koordináció és finanszírozás hiányában - jelenleg nem biztosított. ${ }^{2}$

\section{A finn KiVa Program hazai adaptációja}

A KiVa Programot az iskolai bántalmazás nemzetközileg elismert kutatói, Prof. Christina Salmivalli és Elisa Poskiparta (University of Turku) fejlesztették ki, több évtizedes kutatómunkájukra építve. Finnországban már egy évtizede nemzeti programnak számít, hiszen az iskolák kb. 90 százaléka alkalmazza a KiVa-t, amely évente 20-30 százalékkal csökkenti a bántalmazás előfordulását. A KiVa egyszerre prevenciós és intervenciós program: a megelőzést szolgáló programelemek minden diákra irányulnak adott osztályfokon, míg az intervenciós lépések csak az aktuálisan előforduló bántalmazásban érintett diákokra vonatkoznak. A két komponens nem is szétválasztható, hiszen a beavatkozás sikeressége az előkészítő munkában rejlik (lehet hivatkozni a jelenség ismeretére, a közösen kidolgozott bántalmazásellenes szabályokra), a problémaérzékenyítés során pedig a diákoknak meg kell tapasztalniuk, hogy az iskola is komoly problémának tekinti a bántalmazást és fellép ellene (Jármi-Péter-Szarka-Fehérpataky 2015).

$\mathrm{A} z$ első, illetve az ötödik osztályban bevezethető KiVa foglalkozások 10 dupla órát jelentenek. A foglalkozásokat minden esetben az osztályfőnök tartja, aki így a közösség formálódásának időszakától kezdve mélyebben megismerheti diákjait, és ezáltal erősödhet közöttük a bizalmi kapcsolat. A KiVa órákon a pedagógusok változatos, interaktív módszerekkel dolgoznak: csoportos megbeszélés, vita, szerepjáték, csoportmunka, film. A tanári kézikönyvben minden témához részletes óravázlatok és a megvalósítást segítő instrukciók tartoznak, illetve minden képi/filmes segédanyag is a tanárok rendelkezésére áll. A tanárok a program iskolai bevezetése során egy 2 napos kiképző tréningen ismer-

Bővebben a programról itt: https://felzarkozas.szgyf.gov.hu/page.php?mid=332 [Valamennyi internetes forrás letöltve: 2019.09. 10.] 
kednek meg az osztálytermi foglalkozások tematikájával, ekkor kapnak némi vezetéstechnikai segítséget is ezek sikeres levezetéséhez, az esetkezelést végző KiVa teamtagok (iskolánként 3-4 fö) pedig egy további alkalommal sajátítják el az esetkezelés lépéseit.

A KiVa foglalkozások tematikája az 1,, illetve 5. évfolyamon:

Unit 1 - Témák: Ismerkedés • Érzelmek • A mi osztályunk - mindenki beletartozik - A különbözőség érték • NINCS bántalmazás a KiVa-iskolában • NEM veszünk részt bántalmazásban $\bullet$ Szükség van a támogatásodra $\bullet$ NEM válok áldozattá $\bullet$ Szépirodalmi óra $\bullet$ KiVa-szerződés

Unit 2 - Témák: Tiszteletet mindenkinek • Csoportban lenni • A bántalmazás felismerése $\bullet$ A bántalmazás rejtett formái $\bullet$ A bántalmazás következményei $\bullet A$ csoport szerepe a bántalmazás folyamatában • Szembeszállás a bántalmazással - csoportként - Mit tegyek, ha bántalmaznak? • KiVa-iskola - csináljuk együtt • Hogyan csináljuk?

A KiVa foglalkozások vonzerejét a KiVa számítógépes játék adja, ami az órákon, illetve otthon is játszható, és lehetőséget ad arra, hogy a diákok az online térben gyakorolják az elsajátított készségek alkalmazását.

A KiVa módszertana alaposan kidolgozott, és jól átlátható struktúrájú, így a magyar iskolákba is könnyen implementálhatónak bizonyult. 2016-2018 között az Oktatáskutató és Fejlesztő Intézet koordinálásával három iskolában történt kísérleti bevezetés, amely bíztató eredményekkel kecsegtetett mind a bántalmazás visszaszorítása, mind a közösség szemléletformálása terén (Györgyi et al. 2018). A szerzők azonban azt is hangsúlyozzák, hogy a pozitív kimenet részben a tantestület nyitottságának, elkötelezettségének köszönhető. Kérdés, hogy még egy ilyen bizonyítottan hatékony program, aminek minőségi bevezetését, az iskolák programhüségét többféle módon igyekszik erősíteni a programgazda, sikeres tudna-e lenni olyan intézményekben is, ahol kötelezö jellegű a bevezetése. A program széles körü disszeminációja a folyamatos részvételi díj miatt (amit /fó/év kell fizetni a finn programgazdának) sajnos elmaradt, a hazai licenccel rendelkező szervezet további bevezetést nem tett lehetővé, és a hároméves szerződés lejárta után hosszabbítás - egyelöre - nem történt. ${ }^{3}$

\section{Az ENABLE Program}

$\mathrm{A} z$ ENABLE (European Network Against Bullying in Learning and Leisure Environments) iskolai bántalmazásellenes programot az European Schoolnet nemzetközi projektjének keretében dolgozták ki 2016-ban. Nagy-Britannia, Dánia, Görögország, Horvátország, Belgium, Luxemburg után 2017 őszétől hazánkban is bevezetésre került. A program magyar adaptációja Jármi Éva és Várnai Dóra munkája, bevezetését az Oktatási Hivatal koordinálja. A 30 órás ENABLE felkészítő tréningeket országosan a Pedagógiai Oktatási Központok szervezik olyan kiképzett iskolapszichológus/pedagógus trénerekkel, akik a pilot szakaszban megvalósították a programot saját iskolájukban és részt vettek a tartalmi fejlesztésében. Ennek azért van nagy jelentősége, mert így biztosított a képzők hitelessége és segíti a résztvevők gyakran erős ellenállásának (lásdः „nem lehet beépíteni az órarendbe”, „ez 30 fös osztályban nem müködik”, ,a diákokat nem lehet bevonni”) oldását.

$\mathrm{A} z$ ENABLE középiskolai program, a foglalkozások módszertana épít a diákok önismereti igényére, absztrakt gondolkodására és a kortársvisszajelzések fontosságára, emi-

3 Bővebben a programról itt: http://www.kivaprogram.net/hu 
att 6-11. évfolyamon ajánlott. A tanév során tíz tanórát ölelnek fel, ezt a megvalósító osztályfőnök elsősorban az osztályfőnöki órák keretében tartja, lehetőség szerint egy másik pedagógus kolléga vagy az iskolapszichológus közremüködésével.

A csoportfoglalkozások tematikája kétféle lehet: SEL és Antibullying modul. A központi SEL modul (Social Emotional Learning) közvetettebb módon érinti a bántalmazás jelenségét, több hangsúlyt fektet a saját és mások érzelmeinek felismerésére, szabályozására, a következményeket mérlegelő viselkedésirányításra, a társas felelősségvállalásra és a kapcsolatkezelésre. Azokat a társas-érzelmi készségeket fejlesztjük tehát, amelyek alkalmassá teszik a bántalmazásban különböző szerepekben érintett diákokat arra, hogy megállítsák a bántalmazást. Ha javul a diákok érzelmi intelligenciája, akkor:

A SZEMLÉLÖK megértik a bántalmazás csoportdinamikáját, az áldozat negatív érzéseit, erősödik empátiájuk, felismerik saját felelősségüket és lehetőségüket a beavatkozásra és az áldozat támogatására;

AZ ÁLDOZATOK felismerik saját erősségeiket, javul megküzdési képességük, így kevésbé lesznek „vonzó célpontok” és kiszolgáltatottak a bántalmazás negatív hatásainak;

A BÁNTALMAZÓK felismerik saját negatív érzéseiket és ezek szerepét bántalmazó viselkedésükben, és kezelni tudják ezeket nem bántalmazás révén.

A SEL modul témakörei:

1. Az érzelmi intelligencia területei

2. Hogy vagy (de igazán)?

3. Érzelmek felismerése társas helyzetekben

4. A bántalmazás természete

5. Ez nem bántalmazás, ez csak (önfelmentő stratégiák)

6. Hogyan lépj közbe egy bullying helyzetben?

7. Hogyan támogathatod a bántalmazás áldozatát?

8. Hogyan birkózzunk meg a rossz érzésekkel?

9. A változás alapjai

10. Hogyan tovább?

Az Antibullying modul az első pillanattól kezdve az iskolai bántalmazásra fókuszál, célja a közösség bullying-ellenes attitűdjének erősítése, bullying-ellenes csoportnorma képzése, és erre vonatkozó osztályszabályok bevezetése.

$\mathrm{Az}$ Antibullying modul témakörei

1. Mit jelent a bullying (iskolai bántalmazás)?

2. Miért lesz áldozat?

3. Miért lesz bántalmazó?

4. Tévhitek a bántalmazásról

5. Reakciók a bántalmazásra

6. Indirekt beavatkozás - támogatás

7. Indirekt beavatkozás - pozitív társas viselkedés

8. Direkt beavatkozás - közbelépés bullying helyzetekben

9. A bántalmazás jelzése - segítségkérés

10. Tegyünk együtt azért, hogy ne legyen bullying az osztályban!

A foglalkozások változatos munkaformákat és oktatási módszereket alkalmaznak, de - különösen a SEL modul esetében - a pedagógusnak nem kell jelentősen eltérnie a 
hagyományos óravezetéstől. A megvalósítást segítik a kész segédanyagok: filmek, képek és power pointok, illetve a tanári kézikönyvben részletes óravázlatok, további gyakorlatjavaslatok találhatók. A program erősen épít a digitális technikák alkalmazására, amenynyiben erre lehetőség van az iskolában.

Az ENABLE Program bevezetése jelenleg még csak osztály szinten történik, a téma iránt elkötelezett, innovatív pedagógusok részvételével, akik remélhetőleg a változás motorjává tudnak válni az intézményen belül - az vezetőség támogatása esetén. A csoportfoglalkozásokat azonban már most is kiegészíti a szülők tájékoztatása, bevonása: a nekik szóló kiadvány egyrészt útmutatót nyújt, mi a teendő szülőként, ha gyermeke hozzá fordul segítségért, másrészt informálja a szülőket arról, mit tehet ő (és mit az iskola) preventív jelleggel. A szülői értekezleten kívül a programba bekapcsolódó kollégák a nevelötestületnek is tartanak rövidebb-hosszabb érzékenyítő előadást a bántalmazásról, a program üzeneteiről, és arról, hogy miben van szükség a többi pedagógus együttmüködésére. A felkészítő képzéseken továbbá elsajátítják a bullying esetek hatékony kezelésének lépéseit, ami kiindulópontként szolgálhat egy iskolai eljárásrend kialakításához, de ennek bevezetése szervezeti szinten kell, hogy történjen. Folyamatban van továbbá egy olyan online diagnosztikai eszköz bevezetése a program minőségi bevezetése és eredményességének nyomon követése érdekében, ami a pedagógusoknak képet nyújt az osztályon belüli viszonyokról a bullying szerepek tekintetében, miközben adatokkal szolgál a program fókuszában álló változók alakulásáról a programgazdának.

$\mathrm{A} z$ ENABLE képzések az iskolák számára térítésmentesen, helyben elérhetők (a költségvetési keret kimerítéséig), sőt a foglalkozásvázlatok bárki számára letölthetők, de a program implementációjának monitorozására, szakmai támogatására sajnos nem biztosított a forrás, pedig ez a sikeresség egyik záloga. ${ }^{4}$

\section{További antibullying kezdeményezések, projektek}

Az elmúlt években több hazai szervezet tüzte zászlójára az iskolai és az internetes bántalmazás elleni fellépést, így mára sok hasznos eszköz magyarul is rendelkezésre áll, amit a téma iránt érdeklődő szakembereknek ajánlani tudunk.

\section{Békés Iskolák}

A Békés Iskolák kezdeményezés az eddig bemutatott átfogó programokhoz hasonlóan rendszerszintü beavatkozást céloz a mozgalomba bekapcsolódó iskolákban, ugyanis az iskola teljes közösségénél igyekszik változást elérni, elsősorban a bántalmazás minden formájának elutasítása és a szemlélők mozgósítása terén. Különlegessége, hogy erősen épít az alulról szerveződő önkéntesség erejére, vagyis az iskola belső erőforrásainak mozgósítását igényli. Nem kínálnak kész programot, hanem tájékoztató előadások, képzések révén elindítják az iskolában a szemléletváltást, és szakmai támogatást nyújtanak azoknak az iskolai szereplőknek (tanároknak, igazgatónak, iskolapszichológusnak), akik elköteleződnek a változás mellett, és akik vezetésével az iskola kidolgozza a saját igényeihez, lehetőségeihez legjobban illeszkedő módszertant. A program elméleti alapköve Twemlow és Sacco (2012) Miért nem müködnek az iskolai bántalmazásellenes programok

4 Bővebben a programról itt: https://hirmagazin.sulinet.hu/hu/s/enable 
című könyve, kulcsfogalma pedig a mentalizáció (amikor magunknak/másoknak mentális állapotokat - szándékot, vélekedést, érzést - tulajdonítunk), aminek hiányában a másik embert tárgyiasítjuk, ez pedig melegágya az erőszaknak. A bántalmazás megelőzésének eszköze tehát egy jól mentalizáló közösség kialakítása, amit közösségformálás mellett a diákok társas-érzelmi készségek fejlesztésén, az erőszakmentes kommunikáció erősítésén és békés konfliktuskezelési (resztoratív) technikák bevezetésén keresztül lehet elérni. A Békés Iskolák filozófiája az, hogy ha az intézményben kialakul egy mentalizáló légkör, ahol a közösség tagjai (tanárok és diákok egyaránt) békésen tudják kifejezni szükségleteiket, és ezekre empatikusan reagálnak a többiek, akkor tartósan megszüntethető a bántalmazás.

Ennek a megközelítésnek az erőssége egyben a legnagyobb nehézsége is, ugyanis a rendkívül ambiciózus célkitűzések megvalósításához csak támpontokat kínál, a saját program kidolgozása nagy erőfeszítést és kreativitást igényel az iskola részéről. Sajnos kevés olyan intézmény van, ahol a közösség elkötelezettsége, együttmüködési készsége és a szervezet teherbírása megfelelő ahhoz, hogy önként belevágjon egy ilyen átfogó szervezetfejlesztésbe, és valóban készen áll a sikeres megújulásra. ${ }^{5}$

\section{Színházi eszközök}

A bullying-prevenciós tevékenységek izgalmas müfaja a színházi nevelés, amely során egy többórás interaktív előadáson vesz részt a diákközösség, jellemzően egy-egy iskolai osztály. A színházi formában feldolgozott történet középpontjában mindig valamilyen erkölcsi/társadalmi probléma áll, amin a színész-drámatanárok és a néző diákok közösen gondolkoznak. A témát több szempontból tudják megközelíteni a résztvevők, ütköztethetik nézeteiket és a dráma nyelvén tudnak párbeszédbe kerülni egymással, amikor a történet fordulópontjain döntéseket kell hozni a következő eseményekről, mint pl. hogyan reagálnak a különböző szereplők a bántalmazási helyzetre, sikerül-e megvédenie magát a bántalmazás célpontjának. Mivel az előadások célja nem egy konkrét üzenet átadása, hanem a dilemma megfogalmazása és megvizsgálása, illetve a vélemények mellett az érzések mozgósítása, ezért ideális kiindulópontjai lehetnek a témához kapcsolódó csoportfoglalkozásoknak. Gyakran tapaszzalható például áldozathibáztatás és a bullying morális támogatása (Lendvai et al. 2018), amit csak lassan, több érzékenyítő alkalom gyakorlatán keresztül lehet érdemben megváltoztatni. A Káva Kulturális Mühely, illetve a Nyitott Kör Egyesület több projekttel, előadással is fontos szereplője ennek a területnek, utóbbihoz kapcsolódik egy ritka és értékes kutatás is, ami két előadás („Stréber”, ill. „Testképmutogatók”) hatását kvantitatív és kvalitatív módon vizsgálta a diákok bullyinggal kapcsolatos tudására és attitüdjére (Lendvai et al. 2018).

Kissé más módszertannal dolgoznak azok a társulatok, akik egy kész színpadi művet mutatnak be színházban vagy osztálytermi környezetben, amit aztán közös beszélgetés vagy dramatikus feldolgozás követ. Az elmúlt években magyarul megjelent, kifejezetten bullying tematikájú ifjúsági regények (Kalapos Éva: Massza, Eve Ainsworth: 7 nap) színpadi adaptációja profi színészek tolmácsolásában jut el középiskolásokhoz, akik ezáltal differenciáltabban látják a bullying szereplőit, jobban értik a dinamikáját, kevésbé áldozathibáztatók.

\footnotetext{
A programról bővebben itt lehet tájékozódni: http://bekesiskolak.hu/
} 


\section{Az elöitéletes alapú bullying megelözése}

2015-ben négy civil szervezet összefogásával indult útjára az „Együtt az iskolai zaklatás ellen. Iránymutatás és képzés az iskoláknak kisebbségi diákjaik védelmére" címü projekt. A Háttér Társaság, a Romaversitas Alapitvány, a Társaság a Szabadságjogokért (TASZ) és a Tett és Védelem Alapitvány (TEV) 2016-ban kiadott Útmutatója szerint a társadalmilag hátrányos helyzetű kisebbségek könnyen beazonosítható tagjai a közösségben jelen lévő előítéletesség, rasszizmus miatt igen gyakran válnak bullying áldozatává, ami a csoport rejtőzködő tagjaira és az iskolai klímára is rendkívül rossz hatással van. A 2015ben lezajlott kutatásuk adatai - melyben 426 középiskola vett részt - jelzik, hogy a magyar pedagógusok kevéssé érzékelik és kevéssé értékelik problémának az elöítéletes bullying előfordulását, ezért kevés ezt célzó tevékenységet végeznek. A probléma tudatosítása és a pedagógusok információkkal való ellátása jelentette az első lépést, azóta tovább bővült a tájékoztató anyagok és módszertani eszközök köre, föleg az LMBTQI és a fogyatékossággal élő diákokra fókuszálva. A Sokszinüség Oktatási Munkacsoport (SOM) 2019 tavaszán megrendezte az első „Iskolai Sokszinüség Hete” programot, amelyhez kb. 200 pedagógus kapcsolódott, és tartott érzékenyítő foglalkozásokat általánosés középiskolásoknak, felhasználva a SOM által készített kampányanyagokat, kisfilmet és módszertani segédletet. ${ }^{6}$

\section{Biztonságos internethasználat}

A biztonságos internethasználat erősítése, ezen belül az internetes bántalmazás megelözése és az áldozatsegítés egyik alappillére a bevezetőben említett Safer Internet Program, amely már tízéves múltra tekint vissza hazánkban. A pedagógusok számára nagy segítség, hogy külső szakértőt tudnak meghívni, aki az adott csoport igényeihez szabottan tart interaktív foglalkozást „Netezz biztonságosan” címmel. Egy egyszeri másfél órás alkalom természetesen arra nem elegendő, hogy minden felmerülő témát közösen feldolgozzanak, de lehetőséget teremt arra, hogy a diákok elkezdjék megfogalmazni kérdéseiket, és önállóan vagy tanári támogatással folytassák a válaszok keresését a program weboldalán található tájékoztató kiadványok segítségével. Gyakran a tanárok is tanulnak a meghívott előadótól és a diákok bevonódását látva, dilemmáikat hallva szánják rá magukat arra, hogy bővítsék ismereteiket és felvállalják ezt a témát. A program kisfilmeket, gyakorlatsorokat („Web We Want”) és oktató társasjátékot („Lájkvadász”) is kínál, amelyek segítenek pl. az adatvédelmi beállításokban, az álhírek és álprofilok felismerésében, a netikett betartásában, és felkészítenek arra, hogy mi a teendő internetes bántalmazás esetén.

Említést érdemel még a Televele Médiapedagógiai Mühely, amely több korosztálynak dolgozott ki tananyagot (pl. az 5-6. osztályosoknak szóló TANDEM program az internetbiztonságra és a médiaerőszak megelőzésére fókuszál), és igény szerint szakembereik meg is tartják a foglalkozásokat. ${ }^{8}$

\footnotetext{
Bővebben a programokról: http://iskolaizaklatas.hu/ és http://sokszinusegoktatas.hu/

A programról bővebben itt: http://www.saferinternet.hu/

8 Bővebben az egyesület programjairól itt: http://televele.hu/
} 
A mai napig sokan használják a $T A B B Y$ Projekt videóit és a pedagógusoknak írt információs füzetet, de sajnos az ezekhez tartozó kockázatbecslő kérdőív, a pedagógusok képzése és szupervíziója a projekt lezárulta után megszünt. ${ }^{9}$

Egy másik módja a felnőtt nevelők (pedagógusok és szülők) többségét jellemző digitális kompetenciahiány áthidalására, ha az online világban a kortárs mentorok veszik át a vezető szerepet. Erre példa a föváros XII. kerületének Hegyvidéki ONvédelem Programja, amelynek keretében a szülők és a pedagógusok edukálásán kívül kortárs mentorokat is képeznek, hiszen a kiskamaszok a náluk néhány évvel idősebb 10. osztályos középiskolásoktól szívesebben fogadnak el iránymutatást a világháló okos használatához. Az azonban az iskolán múlik, hogy mennyire tud belesimulni a kortárs segítés a szervezet müködésébe, megerősödik-e ennek kultúrája az intézményben. ${ }^{10}$

2016-ban érvénybe lépett a magyar Kormány Digitális Gyermekvédelmi Stratégiája, amely több szálon kapcsolódik az internetes bántalmazás prevenciójához (pl. hotline üzemeltetése, a „Büvösvölgy” Médiaértés-oktató Központok elérhetővé tétele iskolai osztályok számára, szürőszoftverek iskolai telepítésének szabályozása), de sajnos ez kevéssé ismert a pedagógusok körében. Ma is érvényes az alapvető jogok biztosának egyik megállapítása (AJB-479/2016), miszerint az internetes bántalmazást elszenvedő diákok kevéssé kapnak segítséget tanáraiktól, mert a pedagógusok az iskolai bántalmazás online térben való megjelenését nem tekintik hatáskörükbe tartozó problémának.

\section{Összegzés}

A tanulmány eddig talán azt a benyomást kelti az olvasóban, hogy a magyar prevenció az elmúlt tíz évben felzárkózott a nemzetközi mezőnyhöz, hiszen rengeteg erőfeszítés történt, hogy legyenek hazánkban is elérhető módszertanok, és megtörténjen az a szemléletváltás, amely a diákok közötti bántalmazó magatartást nem tekinti a közösségek természetes velejárójának. Valóban számos színvonalas anyag született a témában, azonban sajnos hosszú utat kell még megtenni addig, amíg

- a bullying-ellenes gyakorlatok széles körben ismertté válnak az iskolákban, óvodákban;

- azok az intézmények (pedagógusok) is elköteleződnek a bántalmazás elleni fellépés mellett, ahol más súlyos problémák is jelzik a közösség diszfunkcióit;

- amíg a bullying-prevencióban érintett intézmények, szakmai irányítók és az iskolák összehangoltan, tervszerüen, egy irányba tesznek lépéseket;

- a bullying-prevenció beépül az iskolák mindennapjaiba, nem kampányszerüen, illetve projekt keretben valósul meg a bullying-ellenes tevékenység;

- tudományos igényességü hatékonyságvizsgálatok követik a programokat;

- a területre folyamatos forrás biztosított.

9 A projekt honlapja: http://tabby-hun.weebly.com/

10 Bővebben a programról itt: https://www.hop12.hu/ 


\section{IRODALOM}

Az alapvető jogok biztosának jelentése a 479/2016. számú ügyben https://www.ajbh.hu/ documents/10180/2500969/Jelent\%C3\%A9s+a+m\%C3\%A9dia\%C3\%A9rt\%C3\%A 9s-oktat\%C3\%A1s+helyzet\%C3\%A9r\%C5\%911+497_2016/41838d72-616e-45bf-8b51e744c4fa1b59?version=1.0 [Letöltve: 2019. 09. 10.]

Buda M. (2015) Az iskolai zaklatás. Szaktárnet-könyvek. Debrecen, Debreceni Egyetemi Kiadó.

Digitális Gyermekvédelmi Stratégia. https://www.kormany.hu/download/6/0e/c0000/ Magyarorsz\%C3\%A1g\%20Digit\%C3\%A1lis\%20Gyermekv\%C3\%A9delmi\%20 Strat\%C3\%A9gi\%C3\%A1ja.pdf [Letöltve: 2019. 09. 10.]

Fótiné Németh M. (2010) Prevenciós-edukációs programok. Rendszerszemléletű megközelítés az iskolai agresszió megelőzésében és kezelésében. In: Fótiné NÉMETH M. (ed.) Kölcsönhatások. Budapest, Mérei Ferenc Fơvárosi Pedagógiai és Pályaválasztási Tanácsadó Intézet. pp. 6-22.

György Z., Imre A., Jankó K. \& Szemerszki M. (2018) A bántalmazás ellen - egy program elsö hazai tapasztalatai. https://ofi.hu/publikacio/bantalmazas-ellen-egy-programelso-hazai-tapasztalatairol [Letöltve: 2019. 09. 10.]

Jármi É., Péter-Szarka Sz. \& Fehérpataky B. (2015) A KiVa-program hazai adaptálásának lehetöségei. http://iskon.opkm.hu/admin/upload/KIVA_adaptacios_tanulmany.pdf [Letöltve: 2019. 09. 10.]

Jármi É. \& Piros V. (2017) Az iskolai bántalmazás (bullying). In: N. Kollár K. \& Szabó É. (eds) Pedagógusok pszichológiai kézikönyve 3. Budapest, Osiris Kiadó. pp. 266-286.

Lendvai L., Horváth L., Dóczi-Vámos G. \& Jozifek Zs. (2018) Benne vagy? A színházi nevelés alkalmazási lehetöségei a bullyinggal kapcsolatos tudatosság növelésére. Budapest, Nyitott Kör Egyesület.

Németh Á. \& Költő A. (2016) Egészség és egészségmagatartás iskoláskorban 2014. Budapest, Nemzeti Egészségfejlesztési Intézet.

Olweus, D. (1999) Iskolai zaklatás. Educatio, Vol. 8. No. 4. pp. 717-739.

Simon D., Zerinváry B. \& Velkey G. (2015) Zárótanulmány a TÁMOP-3.1.1-11/1-2012-0001 "Iskolai agresszió, online és hagyományos zaklatás vizsgálata az iskolai közérzet alakulásával és az alkalmazott pedagógiai és konfliktuskezelési eszközökkel összefüggésben" c. projekthez. http://iskon.opkm.hu/admin/upload/Osszegzo_ tanulmany.pdf [Letöltve: 2019. 10. 02.]

Twemlow, S. W. \& SAcco, F. C. (2012) Miért nem müködnek az iskolai bántalmazás-ellenes programok? Budapest, Flaccus Kiadó.

Várnai D. E., Jármi É., Arnold P., Demetrovics Zs., Németh Á., Kökönyei Gy. \& ÖrKÉNYI Á. (2018) A kortársbántalmazás (bullying) értelmezésének vizsgálata kvalitatív módszerrel. - „Az Iskoláskorú Gyermekek Egészségmagatartása” (HBSC) vizsgálat módszertanának kiegészítésére. Magyar Pszichológiai Szemle, Vol. 73. No. 4. pp. 519-539.

A cikk a Creative Commons Attribution 4.0 International License (https://creativecommons.org/licenses/ by/4.0/) feltételei szerint publikált Open Access közlemény, melynek szellemében a cikk bármilyen médiumban szabadon felhasználható, megosztható és újraközölhető, feltéve, hogy az eredeti szerző és a közlés helye, illetve a CC License linkje és az esetlegesen végrehajtott módosítások feltüntetésre kerülnek. (SID_1) 